\title{
PENGARUH MOTIVASI KERJA TERHADAP PRESTASI KERJA KARYAWAN PT. ALVA KARYA PERKASA BANDUNG
}

\author{
${ }^{1}$ Wandy Zulkarnaen; ${ }^{2}$ Iis Dewi Fitriani; ${ }^{3}$ Rini Widia \\ ${ }^{1,2,3}$ STIE Muhammadiyah Bandung \\ Jl. Karapitan No.143 Bandung \\ ${ }^{1}$ Email : wandy.zulkarnaen@stiemb.ac.id
}

\begin{abstract}
Abstrak
Suatu perusahaan yang ingin melaksanakan tugas dan fungsinya dengan baik, maka perusahaan tersebut akan berusaha untuk merubah para pegawainya agar mempunyai mutu serta kinerja yang baik, sehingga membuat para pegawainya lebih produktif dalam menjalankan tugas dan tanggung jawab mereka. Untuk memperoleh pegawai yang sesuai dengan apa yang diharapkan, maka perlu adanya motivasi bagi karyawan. Untuk memotivasi karyawan, manajer harus mengetahui motif dan memotivasi yang diinginkan karyawan, baik kebutuhan yang disadari maupun kebutuhan yang tidak disadari, berbentuk materi atau non materi, kebutuhan fisik maupun rohani. Prestasi kerja adalah suatu hasil kerja yang dicapai seseorang dalam melaksanakan tugas-tugas yang dibebankan kepadanya didasarkan atas kecakapan, pengalaman, dan kesungguhan serta waktu.

Metode penelitian yang digunakan adalah metode Deskriptif. Deskriptif adalah metode yang berfungsi untuk mendiskripsikan atau memberi gambaran terhadap obyek yang diteliti melalui data sample atau populasi sebagaimana adanya, tanpa melakukan analisis dan membuat kesimpulan yang berlaku untuk umum.Pada metode deskriptif ini, akan dikemukan cara - cara penyajian data, dengan tabel biasa maupun distribusi frekuensi; grafik garis maupun batang; diagram lingkaran; pictogram; penjelasan kelompok melalui rentang dan simpangan baku.

Dari hasil penelitian diketahui bahwa seluruh item pertanyaan menunjukkan hasil yang valid dimana semua nilai $\mathrm{R}$ kritis-nya berada di atas nilai titik kritis yaitu $>0.300$. Sedangkan hasil uji reliabilitas pada variabel tersebut menunjukkan hasil yang reliabel dimana semua nilai $\mathrm{R}$ kritis-nya berada di atas nilai titik kritis yaitu $>0.600$ dengan rincian : R kritis variable motivasi kerja sebesar 0.823 serta $\mathrm{R}$ kritis variable prestasi kerja sebesar 0.846. Dari hasil pengolahan SPSS diperoleh persamaan regresi linier berganda sebagai berikut : $\mathrm{Y}=11,495+0,722 \mathrm{X}$. Adapun berdasarkan hasil koefisien determinasinya diperoleh data variabel $\mathrm{X}$ (Motivasi Kerja) memiliki pengaruh terhadap variabel Y (Prestasi Kerja) sebesar 49,325\%, sedangkan sisanya sebesar 50,675\% dipengaruhi oleh faktor lain yang tidak diamati.

Berdasarkan hasil analisis deskriptif data penelitian untuk variabel Motivasi Kerja, maka dapat disimpulkan bahwa tanggapan responden tentang Motivasi Kerja termasuk dalam kategori "Rendah". Begitu juga untuk variabel Prestasi Kerja, maka dapat disimpulkan bahwa tanggapan responden tentang Prestasi Kerja termasuk dalam kategori "Rendah". Secara keseluruhan pemaparan analisis perhitungan statistik pada uji korelasi, koefisien determinasi, dan uji hipotesis, dapat diambil kesimpulan bahwa,
\end{abstract}


secara statistik, pengaruh Motivasi Kerja telah terbukti mempunyai korelasi yang kuat dan signifikan terhadap Prestasi Kerja, dengan pengaruh sebesar 49,325\%. Sedangkan sisa pengaruh sebesar $50,675 \%$ dipengaruhi oleh faktor lain yang tidak diamati.

Kata kunci : Motivasi Kerja dan Prestasi Kerja

\section{PENDAHULUAN}

Pada umumnya setiap perusahaan dalam menjalankan kegiatan operasionalnya membutuhkan beberapa faktor yang mendukung untuk tercapainya kinerja yang baik dan produktifitas yang tinggi. Sumber daya manusia merupakan salah satu faktor terpenting, karena tanpa adanya peran dari sumber daya manusia yang berkualitas, segala aktifitas dalam suatu instansi tidak akan dapat terlaksana secara optimal.

Setiap perusahaan harus menyadari berhasil atau tidaknya tugas dan fungsi yang dilaksanakan tergantung pada faktor sumber daya manusia (SDM). Sumber daya manusia yaitu orang-orang yang memberikan tenaga, bakat, kreatifitas dan usahanya kepada organisasi, perusahaan atau instansi. Bagaimanapun canggihnya sarana dan prasarana yang dimiliki oleh suatu instansi tanpa ditunjang dengan kemampuan pegawai, mustahil perusahaan tersebut dapat maju dan berkembang.

Suatu perusahaan yang ingin melaksanakan tugas dan fungsinya dengan baik, maka perusahaan tersebut akan berusaha untuk merubah para pegawainya agar mempunyai mutu serta kinerja yang baik, sehingga membuat para pegawainya lebih produktif dalam menjalankan tugas dan tanggung jawab mereka. Untuk memperoleh pegawai yang sesuai dengan apa yang diharapkan, maka perlu adanya motivasi bagi karyawan.
Motif adalah suatu perangsang keinginan dan daya penggerak kemauan bekerja seseorang. Setiap motif mempunyai tujuan tertentu yang ingin dicapai. ( Hasibuan : 2012 : 144 )

Motivasi adalah hal yang menyebabkan, menyalurkan, dan mendukung perilaku manusia, supaya mau bekerja giat dan antusias mencapai hasil yang optimal. Motivasi semakin penting karena manajer membagikan pekerjaan pada bawahannya untuk dikerjakan dengan baik dan terintegrasi kepada tujuan yang diinginkan. (Hasibuan : 2012 : 141)

Untuk memotivasi karyawan, manajer harus mengetahui motif dan memotivasi yang diinginkan karyawan, baik kebutuhan yang disadari maupun kebutuhan yang tidak disadari, berbentuk materi atau non materi, kebutuhan fisik maupun rohani.

Prestasi kerja adalah suatu hasil kerja yang dicapai seseorang dalam melaksanakan tugas - tugas yang dibebankan kepadanya didasarkan atas kecakapan, pengalaman, dan kesungguhan serta waktu. Prestasi kerja merupakan gabungan dari tiga faktor penting, yaitu kemampuan dan minat seorang pekerja, kemampuan dan penerimaan atas penjelasan delegasi tugas, serta peran dan tingkat motivasi seorang pekerja. Semakin tinggi ketiga faktor diatas, semakin besarlah prestasi kerja karyawan yang bersangkutan. (Hasibuan 2012 : 94 )

Faktor yang mempengaruhi pencapaian prestasi kerja adalah factor 
kemampuan (ability) dan factor motivasi (motivation).

Berdasarkan hal di atas, untuk menigkatkan prestasi kerja tersebut kedua factor tersebut harus diperhatikan. Dengan kata lain motivasi adalah salah satu factor yang mempengaruhi seorang karyawan meningkatkan prestasi kerjanya.

Demikian pula dengan prestasi kerja karyawan pada perusahaan PT Alva Karya Perkasa yang sesuai dengan potensinya. Harapannya para pegawai dapat menjalankan tugas dan fungsi dengan baik. PT Alva Karya Perkasa sampai saat ini, apakah sudah memberikan motivasi dengan menggunakan atau menjalankan teknik memotivasi kerja karyawan dengan baik, yang nantinya dapat meningkatkan kualitas kerja pada karyawan itu sendiri serta dapat meningkatkan kualitas perusahaan. Prestasi perusahaan dapat meningkat seiring dengan meningkatnya kualitas karyawan.Tentunya dengan barometer yang ada diperusahaan.

Dengan prestasi karyawan di PT Alva Karya Perkasa sementara ini, masalah yang muncul adalah belum maksimalnya bentuk motivasi perusahaan terhadap karyawan untuk meningkatkan kualitas karyawan guna meningkatkan pula prestasi kerja dari perusahaan kepada karyawan. Berikut adalah data pretasi atau pencapaian target karyawan selama 3 tahun terakhir.

Tabel 1. Data Target dan Pencapaian Tahun 2012

\begin{tabular}{|c|c|c|c|c|}
\hline \multicolumn{5}{|c|}{ PERIODE : 2012} \\
\hline \multirow[t]{2}{*}{ NO } & \multirow[t]{2}{*}{ TOKO } & \multicolumn{3}{|c|}{ TOTAL 2012} \\
\hline & & TARGET & ACTUAL & $\%$ \\
\hline & A.MDS & & & \\
\hline 1 & $\begin{array}{l}\text { MATAHARI BANDUNG INDAH } \\
\text { PLAZA }\end{array}$ & $350,700,000$ & $93,812,250$ & $27 \%$ \\
\hline 2 & MATAHARI FESTIVAL CITY & $310,400,000$ & $92,014,250$ & $30 \%$ \\
\hline 3 & MATAHARI ISTANA PLAZA & $311,700,000$ & $95,551,050$ & $31 \%$ \\
\hline & SUBTOTAL MDS & $972,800,000$ & $281,377,550$ & $29 \%$ \\
\hline & B.MODERN TREND & & & \\
\hline 1 & YOGYA KEPATIHAN & $431,400,000$ & $228,585,400$ & $53 \%$ \\
\hline 2 & YOGYA CIWALK & $343,400,000$ & $200,298,650$ & $58 \%$ \\
\hline & SUBTOTAL MODERN TREND & $774,800,000$ & $428,884,050$ & $55 \%$ \\
\hline & C.GT & & & \\
\hline 1 & AT MAHMUD & $225,700,000$ & $232,861,680$ & $103 \%$ \\
\hline 2 & JOVANKA & $61,600,000$ & $10,416,780$ & $17 \%$ \\
\hline 3 & AMI COSMETIK & $116,153,846$ & $19,019,500$ & $16 \%$ \\
\hline 4 & GUARDIAN PVJ & $116,200,000$ & $22,351,700$ & $19 \%$ \\
\hline 5 & GUARDIAN MOBILE & $35,000,000$ & $7,933,400$ & $23 \%$ \\
\hline
\end{tabular}




\begin{tabular}{|r|l|c|c|r|}
6 & SARIAYU SUMEDANG & $122,500,000$ & $40,637,900$ & $33 \%$ \\
\hline 7 & TOKO MELATI & $5,000,000$ & $1,177,350$ & $24 \%$ \\
\hline & SUB TOTAL GT & $287,300,000$ & $243,278,460$ & $85 \%$ \\
\hline & TOTAL BANDUNG & $2,034,900,000$ & $953,540,060$ & $47 \%$ \\
\hline
\end{tabular}

Sumber: Data Pencapaian Target Sikygirl Karyawan Di PT Alva Karya Perkasa

Bandung

Tabel 2. Data Target dan Pencapaian Tahun 2013

\begin{tabular}{|c|c|c|c|c|}
\hline \multicolumn{5}{|c|}{ PERIODE : 2013} \\
\hline \multirow{2}{*}{ NO } & \multirow{2}{*}{ TOKO } & \multicolumn{3}{|c|}{ TOTAL 2013} \\
\hline & & TARGET & ACTUAL & $\%$ \\
\hline & A.MDS & & & \\
\hline 1 & MATAHARI BANDUNG INDAH PLAZA & $255,000,000$ & $325,936,670$ & $128 \%$ \\
\hline 2 & MATAHARI FESTIVAL CITY & $250,000,000$ & $219,888,000$ & $88 \%$ \\
\hline \multirow[t]{3}{*}{3} & MATAHARI ISTANA PLAZA & $250,000,000$ & $200,696,175$ & $80 \%$ \\
\hline & SUBTOTAL MDS & $755,000,000$ & $746,520,845$ & $99 \%$ \\
\hline & B.MODERN TREND & & & \\
\hline 1 & YOGYA KEPATIHAN & $540,000,000$ & $547,962,200$ & $101 \%$ \\
\hline 2 & YOGYA CIWALK & $454,000,000$ & $526,280,665$ & $116 \%$ \\
\hline \multirow[t]{3}{*}{3} & YOGYA RIAU & $75,000,000$ & $71,709,200$ & $96 \%$ \\
\hline & SUBTOTAL MODERN TREND & $994,000,000$ & $1,074,242,865$ & $108 \%$ \\
\hline & C.GT & & & \\
\hline 1 & AT MAHMUD & $342,093,216$ & $332,472,780$ & $97 \%$ \\
\hline 2 & AMI COSMETIK & $152,500,000$ & $60,078,000$ & $39 \%$ \\
\hline 3 & GUARDIAN PVJ & $147,500,000$ & $33,126,215$ & $22 \%$ \\
\hline 4 & GUARDIAN MOBILE & $147,500,000$ & $16,947,185$ & $11 \%$ \\
\hline 5 & SARIAYU SUMEDANG & $155,000,000$ & $91,812,900$ & $59 \%$ \\
\hline 6 & TOKO MELATI & $150,000,000$ & $67,427,850$ & $45 \%$ \\
\hline 7 & TOKO MUARA TASIK & $125,000,000$ & $79,910,100$ & $64 \%$ \\
\hline \multirow[t]{3}{*}{8} & TOKO JASA MEKAR & $107,500,000$ & $44,662,700$ & $42 \%$ \\
\hline & SUBTOTAL GT & $1,327,093,216$ & $726,437,730$ & $55 \%$ \\
\hline & TOTAL BANDUNG & $3,076,093,216$ & $2,547,201,440$ & $83 \%$ \\
\hline
\end{tabular}

Sumber: Data Pencapaian Target Sikygirl Karyawan Di PT Alva Karya Perkasa

Bandung

Tabel 3. Data Target dan Pencapaian Tahun 2014

PERIODE : 2014 


\begin{tabular}{|c|c|c|c|c|}
\hline \multirow[t]{2}{*}{ NO } & \multirow[t]{2}{*}{ TOKO } & \multicolumn{3}{|c|}{ TOTAL 2014} \\
\hline & & TARGET & ACTUAL & $\%$ \\
\hline & A.MDS & & & \\
\hline 1 & $\begin{array}{l}\text { MATAHARI BANDUNG INDAH } \\
\text { PLAZA }\end{array}$ & $302,000,000$ & $267,970,150$ & $89 \%$ \\
\hline 2 & MATAHARI FESTIVAL CITY & $302,000,000$ & $264,070,940$ & $87 \%$ \\
\hline 3 & MATAHARI ISTANA PLAZA & $340,000,000$ & $318,392,810$ & $94 \%$ \\
\hline 4 & MATAHARI GRAGE MALL & $164,903,846$ & $83,033,150$ & $50 \%$ \\
\hline 5 & MTAHARI CSB MALL & $150,000,000$ & $59,613,575$ & $40 \%$ \\
\hline \multirow[t]{3}{*}{6} & CENTRO CIREBON & $187,500,000$ & $27,092,120$ & $14 \%$ \\
\hline & SUBTOTAL MDS & $1,446,403,846$ & $1,020,172,745$ & $71 \%$ \\
\hline & B.MODERN TREND & & & \\
\hline 1 & YOGYA KEPATIHAN & $768,000,000$ & $676,769,700$ & $88 \%$ \\
\hline 2 & YOGYA CIWALK & $623,000,000$ & $539,070,219$ & $87 \%$ \\
\hline 3 & YOGYA RIAU & $300,000,000$ & $251,880,913$ & $84 \%$ \\
\hline 4 & YOGYA GRAND CIREBON & $212,500,000$ & $73,744,600$ & $35 \%$ \\
\hline 5 & YOGYA GRAND MAJALENGKA & $275,000,000$ & $119,133,290$ & $43 \%$ \\
\hline 6 & CARREFOUR & - & - & \\
\hline 7 & GRIYA MAJALAYA & $225,000,000$ & $81,980,400$ & $36 \%$ \\
\hline 8 & YOGYA SUNDA & $37,500,000$ & $29,750,601$ & $79 \%$ \\
\hline \multirow[t]{3}{*}{9} & GRIYA SUMEDANG & $50,000,000$ & $28,545,760$ & $57 \%$ \\
\hline & SUBTOTAL MODERN TREND & $2,503,500,000$ & $1,816,426,273$ & $73 \%$ \\
\hline & C.GT & & & \\
\hline 1 & AT MAHMUD & $371,564,568$ & $411,451,000$ & $111 \%$ \\
\hline 2 & AMI COSMETIK & $160,000,000$ & $93,377,500$ & $58 \%$ \\
\hline 3 & TOKO RAMA SHINTA & $164,733,700$ & $166,473,450$ & $101 \%$ \\
\hline 4 & SARIAYU SUMEDANG & $160,000,000$ & $130,660,750$ & $82 \%$ \\
\hline 5 & TOKO MELATI & $160,000,000$ & $99,439,400$ & $62 \%$ \\
\hline 6 & TOKO MUARA TASIK & $162,500,000$ & $115,147,900$ & $71 \%$ \\
\hline 7 & TOKO JASA MEKAR & $160,000,000$ & $98,963,700$ & $62 \%$ \\
\hline 8 & WATSON & $87,500,000$ & $108,731,848$ & $124 \%$ \\
\hline 9 & TOKO JELITA & $122,500,000$ & $78,937,900$ & $64 \%$ \\
\hline 10 & TOKO ENDRO & $15,000,000$ & $5,817,250$ & $39 \%$ \\
\hline 11 & TOKO BLITAR & $147,500,000$ & $36,291,625$ & $25 \%$ \\
\hline \multirow[t]{2}{*}{12} & TOKO DAUN INDAH & $147,500,000$ & $22,631,550$ & $15 \%$ \\
\hline & SUBTOTAL GT & $1,858,798,268$ & $1,367,923,873$ & $74 \%$ \\
\hline
\end{tabular}




\begin{tabular}{|l|l|l|l|l|} 
TOTAL BANDUNG \& CIREBON & $5,808,702,114$ & $4,204,522,891$ & $72 \%$ \\
\hline
\end{tabular}

Sumber: Data Pencapaian Target Sikygirl Karyawan Di PT Alva Karya Perkasa Bandung

Tabel 4. Data Target dan Pencapaian Tahun 2012 - 2014

\begin{tabular}{|c|c|c|c|c|}
\hline NO & Tahun & Target & Pencapaian & $\%$ \\
\hline 1 & 2012 & $2,034,900,000$ & $953,540,060$ & $47 \%$ \\
\hline 2 & 2013 & $3,076,093,216$ & $2,547,201,440$ & $83 \%$ \\
\hline 3 & 2014 & $5,808,702,114$ & $4,204,522,891$ & $72 \%$ \\
\hline
\end{tabular}

Dari hasil data pencapaian yang diperoleh dari narasumber sebagai acuan prestasi kerja karyawan bahwa pencapaian target karyawan menurun dari tahun 2013 mencapai $83 \%$ dan tahun 2014 hanya mencapai $72 \%$.

Berdasarkan hasil wawancara juga yang dilakukan penulis dengan HRD dan PIC di PT Alva Karya Perkasa Bandung, yang mewakili dan membawahi karyawan yang nantinya akan dijadikan responden dalam penelitian selanjutnya, di dalam melihat dan menganalisa karyawan yang memiliki tugas dan kewajiban yang fluktuatif sehingga tidak berfokus pada tugas pokok dari para karyawan tersebut.Tugas pokok yang memang menjadi kewajiban adalah handling people. Sedangkan sifat setiap orang berbeda menjadikannya pekerjaan yang unik, seni yang dimainkan karena kreatifitas dalam setiap penanganan orang dan setiap masalahnya bisa berbeda. Akan tetapi dalam kurun beberapa tahun ke belakang pengembangan karyawan sudah tidak diadakan lagi diperusahaan ini, sedangkan pengembangan karyawan perlu dan dirasa penting, tidak hanya untuk karyawan itu sendiri tetapi juga untuk perusahaan.

\section{KERANGKA TEORITIS \& HIPOTESIS \\ Prestasi Kerja Karyawan}

Prestasi merupakan hasil nyata dari puncak pengembangan potensi diri. Prestasi hanya dapat diraih dengan mengerahkan segala kekuatan, kemampuan dan usaha yang ada dalam diri kita. Prestasi diartikan sebagai hasil usaha yang dicapai dari apa yang dikerjakan atau yang diusahakan. Seseorang dianggap berprestasi, jika dia telah meraih sesuatu hasil dari apa yang diusahakannya, baik karena hasil belajar, bekerja, atau berlatih keterampilan dalam bidang tertentu. Prestasi merupakan hasil nyata dari puncak pengembangan potensi diri. Prestasi hanya dapat diraih dengan mengerahkan segala kekuatan, kemampuan dan usaha yang ada dalam diri kita.

Prestasi kerja adalah suatu hasil kerja yang dicapai seseorang dalam melaksanakan tugas - tugas yang dibebankan kepadanya didasarkan atas kecakapan, pengalaman, dan kesungguhan serta waktu. Prestasi kerja merupakan gabungan dari tiga faktor penting, yaitu kemampuan dan minat seorang pekerja, kemampuan dan 
penerimaan atas penjelasan delegasi tugas, serta peran dan tingkat motivasi seorang pekerja. Semakin tinggi ketiga faktor diatas, semakin besarlah prestasi kerja karyawan yang bersangkutan. ( Hasibuan 2012 : 94 )

Pengertian prestasi kerja adalah hasil kerja secara kualitas dan kuantitas yang dicapai oleh seorang pegawai dalam melaksanakan tugasnya sesuai dengan tanggung jawab yang diberikan kepadanya. ( Mangkunegara 2011: 67 )

Menurut The Scribner Bantam English Dictionary, 1979 dalam buku Soedarmayanti 2014 : 259, yang sudah diterjemah kedalam bahasa Indonesia, kinerja artinya :

1. Melakukan, menjalankan, melaksanakan

2. Memenuhi atau menjalankan kewajiban suatu nazar

3. Menggambarkan suatu karakter dalam suatu permainan

4. Menggambarkannya dengan suara atau alat music

5. Melaksanakan atau menyempurnakan tanggung jawab

6. Melakukan suatu kegiatan dalam suatu permainan

7. Memainkan ( pertunjukan ) music

8. Melakukan sesuatu yang diharapkan oleh seseorang atau mesin.

Faktor - Faktor yang Mempengaruhi Prestasi Kerja

Faktor yang mempengaruhi pencapaian kinerja adalah faktor kemampuan (ability)dan faktor motivasi (motivation ). Hal ini sesuai dengan pendapat Keith Davis, ( 1964 : 484 ) yang merumuskan bahwa :

$\begin{array}{ll}\text { Human Performance } & =\text { Ability }+ \\ \text { Motivation } & = \\ \text { Motivation } & \text { Attitude } \\ \text { + Situation } & \end{array}$

* Ability =

Knowledge + Skill

a. Faktor Kemampuan

Secara psikologis,

kemampuan (ability) pegawai terdiri dari kemampuan potensi (IQ) dan kemampuan reality ( Knowledge + Skill ). Artinya, pegawai yang memiliki IQ di atas rata-rata (IQ 110-120) dengan pendidikan yang memadai untuk jabatannya dan terampil dalam mengerjakan pekerjaan sehari hari, maka ia akan lebih mudah mencapai kinerja yang diharapkan. Oleh karena itu, pegawai perlu ditempatkan pada pekerjaan yang sesuai dengan keahliannya ( the right man in the right place, the right man on the right job).

b. Faktor Motivasi

Motivasi terbentuk dari sikap ( attitude) seorang pegawai dalam menghadapi situasi (situation) kerja. Motivasi merupakan kondisi yang menggerakan diri pegawai yang terarah untuk mencapai tujuan organisasi ( tujuan kerja ).

Sikap mental merupakan kondisi mental yang mendorong diri pegawai untuk berusaha mencapai prestasi kerja secara maksimal. Sikap mental seorang pegawai harus sikap mental yang siap secara psikofisik ( siap secara mental, fisik, tujuan, dan situasi ). Artinya, seorang pegawai harus siap mental, mampu secara fisik, memahami tujuan utama, dan target kerja yang akan dicapai, mampu memanfaatkan, dan menciptakan situasi kerja. Sikap mental yang siap secara psikofisik terbentuk karena pegawai mempunyai "MODAL dan KREATIF “. Modal merupakan singkatan 
dari $\mathrm{M}=$ Mengolah, $\mathrm{O}=$ Otak, $\mathrm{D}=$ Dengan, $\mathrm{A}=$ Aktif, $\mathrm{L}=$ Lincah, sedangkan Kreatif singkatan dari $\mathrm{K}=$ Keinginan maju , $\mathrm{R}=$ Rasa ingin tahu tinggi, $\mathrm{E}=$ Energik, $\mathrm{A}=$ Analisis sistematik, $\mathrm{T}=$ Terbuka dari kekurangan, $\mathrm{I}=$ Inisiatif tinggi, $\mathrm{F}=$ Pikiran luas . Dengan demikian pegawai tersebut mampu mengolah otak dengan aktif dan lincah, memiliki keinginan maju, rasa ingin tahu tinggi, energik, analisis sistematik, terbuka untuk menerima pendapat, inisiatif tinggi, dan pikiran luas terarah.

David C. Mc Clelland ( 1987 ) berpendapat bahwa "ada hubungan yang positif antara motif berprestasi dengan pencapaian kinerja". Motif berprestasi adalah suatu dorongan dalam diri pegawai untuk melakukan suatu kegiatan atau tugas dengan sebaik-baiknya agar mampu mencapai prestasi kerja ( kinerja ) dengan predikat terpuji. Selanjutnya, McClelland mengemukakan 6 karakteristik dari pegawai yang memiliki motif berprestasi tinggi, yaitu pertama, memiliki tanggung jawab pribadi yang tinggi. Kedua, berani mengambil resiko.Ketiga, memiliki tujuan yang realistis.Keempat, memiliki rencana kerja yang menyeluruh dan berjuang untuk merealisasikan tujuannya.Kelima, memanfaatkan umpan balik ( feedback ) yang konkret dalam seluruh kegiatan kerja yang dilakukannya. Keenam, mencari kesempatan untuk merealisasikan rencana yang telah diprogramkan.

Berdasarkan pendapat McClelland tersebut, pegawai akan mampu mencapai kinerja maksimal jika ia memiliki motif berprestasi tinggi. Motif berprestasi yang perlu dimilki oleh pegawai harus ditumbuhkan dari dalam diri sendiri selain dari lingkungan kerja. Hal ini karena motif berprestasi yang ditumbuhkan dari dalam diri sendiri akan membentuk suatu kekuatan kinerja akan lebih mudah. Oleh karena itu, kembangkanlah motif berprestasi dalam diri dan memanfaatkan serta ciptakan situasi yang ada dalam lingkungan kerja guna mencapai kinerja maksimal.

\section{Motivasi Kerja}

Untuk

mempermudah

pemahaman motivasi kerja, dibawah ini dikemukakan pengertian motif, motivasi, dan motivasi kerja. Menurut ( Abraham Sperling ( 1987:183 ) dalam buku Mangkunegara 2011 ) mengemukakan bahwa 'Motive is defined as a tendency to activity, started by a drive and ended by an adjustment. The adjustment is said to satisty the motif'. ( Motif didefinisikan sebagai suatu kecenderungan untuk beraktivitas, dimulai dari dorongan dalam diri (drive) dan diakhiri dengan penyesuaian diri. Penyesuaian diri dikatakan untuk memuaskan motif)

Menurut ( Fillmore H. Stanford dalam buku Mangkunegara 2011 : 93 ) bahwa "Motivation as an energizing condition of the organism that serves to direct that organism toward the goal of a certain class" ( Motivasi sebagai suatu kondisi yang menggerakan manusia ke arah suatu tujuan tertentu.

Dari beberapa pengertian diatas, jadi motivasi adalah kekuatan yang mendorong seseorang untuk melakukan suatu tindakan atau tidak pada hakekatnya ada secara internal dan eksternal yang dapat positif atau negatif untuk mengarahkannya sangat bergantung kepada ketangguhan sang manajer.

Sedangkan menurut ( Ardana, Mujiati, Utama : 2012 : 193 )

motivasi kerja adalah sesuatu yang menimbulkan dorongan atau semangat kerja atau pendorong semangat kerja. 
Pengelolaan organisasi atau perusahaan sangat ditentukan oleh kegiatan pendayagunaan SDM. Berangkat dari sini sangat penting untuk disadari, adanya teknik - teknik untuk dapat memlihara prestasi dan kepuasan kerja karyawan. Salah satunya adalah dengan memberikan dorongan ( motivasi ) kepada bawahan, agar karyawan dapat melaksanakan tugas sesuai uraian tugas dan pengarahan.

Pada dasarnya jenis motivasi tersebut dapat dibagi menjadi tiga yaitu sebagai berikut :

1. Material incentive :pendorong yang dapat dinilai dengan uang.

2. Semi material incentive

3. Non material incentive : yang tak dapat dinilai dengan uang seperti :

- Penempatan yang tepat

- Latihan sistematik

- Promosi yang objektif

- Pekerjaan yang terjamin

- Keikutsertaan wakil - wakil karyawan dalam pengambilan keputusan

- Kondisi pekerjaan yang menyenangkan

- Pemberian informasi tentang perusahaan

- Fasilitas rekreasi

- Penjagaan kesehatan

- Perumahan, dan lain sebagainya.

Tujuan Motivasi

1. Meningkatkan moral dan kepuasan kerja karyawan.

2. Meningkatkan produktivitas kerja karyawan.

3. Mempertahankan kestabilan karyawan perusahaan

4. Meningkatkan kedisiplinan karyawan

5. Mengefektifkan pengadaan karyawan

6. Menciptakan suasana dan hubungan kerja yang baik
7. Meningkatkan loyalitas, kreativitas, dan partisipasi karyawan

8. Meningkatkan tingkat kesejahteraan karyawan

9. Mempertinggi rasa tanggung jawab karyawan terhadap tugas - tugasnya

10. Meningkatkan efisiensi penggunaan alat - alat dan bahan baku.

\section{Prinsip - Prinsip dalam Motivasi Kerja Karyawan}

Terdapat beberapa prinsip dalam memotivasi kerja karyawan.

1. Prinsip Partisipasi

Dalam upaya memotivasi kerja, pegawai perlu diberikan kesempatan ikut berpartisipasi dalam menentukan tujuan yang akan dicapai oleh pemimpin.

2. Prinsip komunikasi

Pemimpin mengkomunikasikan segala sesuatu yang berhubungan dengan usaha pencapaian tugas, dengan informasi yang jelas, pegawai akan lebih mudah dimotivasi kerjanya.

3. Prinsip mengakui andil bawahan Pemimpin mengakui bahwa bawahan (pegawai) mempunyai andil di dalam usaha pencapaian tujuan. Dengan pengakuan tersebut, pegawai akan lebih mudah dimotivasi kerjanya.

4. Prinsip pendelegasian wewenang Pemimpin memberikan otoritas atau wewenang kepada pegawai bawahan untuk sewaktu -waktu dapat mengambil keputusan terhadap pekerjaan yang dilakukannya, akan membuat pegawai yang bersangkutan menjadi termotivasi untuk mncapai tujuan yang diharapkan oleh pemimpin.

5. Prinsip memberi perhatian

Pemimpin memberikan perhatian terhadap apa yang diinginkan 
pegawai bawahan, akan memotivasi pegawai bekerja apa yang diharapkan pemimpin.

\section{Teknik Motivasi Kerja Pegawai}

Beberapa teknik memotivasi kerja pegawai, antara lain sebagai berikut

1. Teknik pemenuhan kebutuhan pegawai

Pemenuhan kebutuhan pegawai merupakan fundamen yang mendasari perilaku kerja. Kita tidak mungkin dapat memotivasi kerja pagawai tanpa memperhatikan apa yang dibutuhkannya.

Dalam buku Mangkunegara 2011:101, Abraham Maslow mengemukakan hierarki kebutuhan pegawai sebagai berikut :

a. Kebutuhan fisiologis, yaitu kebutuhan makan, minum, perlindungan fisik, bernapas, dan seksual. Kebutuhan ini merupakan kebutuhan yang paling mendasar. Dalam hubungan dengan kebutuhan ini pemimpin perlu memberikan gaji yang layak kepada pegawai.

b. Kebutuhan rasa aman, yaitu kebutuhan perlindungan dari ancaman, bahaya, dan lingkungan kerja. Dalam hubungan dengan kebutuhan ini, pemimpin perlu memberikan tunjangan kesehatan, asuransi kecelakaan, perumahan, dan dana pensiun.

c. Kebutuhan sosial atau rasa memiliki, yaitu kebutuhan untuk diterima dalam kelompok unit kerja, berafiliasi, berinteraksi, serta rasa dicintai dan mencintai. Dalam hubungan dengan kebutuhan ini, pemimpin perlu menerima eksistensi/keberadaan pegawai sebagai anggota kelompok kerja, melakukan interaksi kerja yang baik, dan hubungan kerja yang harmonis.

d. Kebutuhan harga diri, yaitu kebutuhan untuk dihormati, dihargai oleh orang lain. Dalam hubungan dengan kebutuhan ini, pemimpin tidak boleh sewenang - wenang memperlakukan pegawai karena mereka perlu dihormati, diberi penghargaan terhadap prestasi kerjanya.

e. Kebutuhan aktualisasi diri, yaitu kebutuhan untuk mengembangkan diri dan potensi, mengemukakan ide ide, memberikan penilaian, kritik, dan prestasi. Dalam hubungannya dengan kebutuhan ini, pemimpin perlu memberi kesempatan kepada pegawai bawahan agar mereka dapat mengaktualisasikan diri secara baik dan wajar di perusahaan.

Selanjutnya, Abraham Maslow dalam buku Mangkunegara berpendapat bahwa orang dewasa (pegawai bawahan) secara normal harus terpenuhi minimal 85 persen kebutuhan fisiologis, 70 persen kebutuhan rasa aman, 50 persen kebutuhan sosial, 40 persen kebutuhan penghargaan, dan 15 persen kebutuhan aktualisasi diri. Jika tidak terpenuhi maka pegawai tersebut akan mengalami konflik diri, keluarga, dan bisa jugamenjadi penyebab terjadinyakonflik kerja. Dengan demikian, jika kebutuhan pegawai tidak terpenuhi, pemimpin akan mengalami kesulitan dalam memotivasi kerja pegawai.

2. Teknik komunikasi persuasive 
Teknik komunikasi persuasive merupakan salah satu teknik memotivasi kerja pegawai yang dilakukan dengan cara mempengaruhi pegawai secara ekstralogis. Teknik ini dirumuskan :“AIDDAS" : $\mathrm{A}=$ Attention (Perhatian); $\mathrm{I}=$ Interest (Minat); $\mathrm{D}=$ Desire (Hasrat); $\mathrm{D}=$ Decision (Keputusan); $\mathrm{A}=$ Action (Aksi/Tindakan); $\mathrm{S}=$ Satisfaction (Kepuasan)

Penggunaannya, pertama kali pemimpin harus memberikan perhatian kepada pegawai tentang pentingnya tujuan dari suatu pekerjaan agar timbul minat pegawai terhadap pelaksanaan kerja, jika telah timbul minatnya maka hasratnya menjadi kuat untuk mengambil keputusan dan melakukan tindakan kerja dalam mencapai tujuan yang diharapkan oleh pemimpin. Dengan demikian, pegawai akan bekerja dengan motivasi tinggi dan merasapuas terhadap hasil kerjanya.

\section{Asas - asas Motivasi}

Asas - asas motivasi ini mencakup asas mengikutsertakan, komunikasi, pengakuan, wewenang yang didelegasikan, dan perhatian timbal balik.

a. Asas Mengikutsertakan

Asas mengikutsertakan maksudnya mengajak bawahan untuk ikut berpartisipasi dalam memberikan kesempatan kepada mereka mengajukan ide - ide, rekomendasi dalam proses pengambilan keputusan. Dengan cara ini, bawahan merasa ikut bertanggung jawab atas tercapainya tujuan perusahaan sehingga moral dan gairah kerjanya akan meningkat.

b. Asas Komunikasi

Asas komunikasi maksudnya menginformasikan secara jelas tentang tujuan yang ingin dicapai, cara mengerjakannya, dan kendala yang dihadapi,. Dengan asas komunikasi, motivasi kerja bawahan akan meningkat. Sebab semakin banyak seseorang mengetahui suatu soal, semakin besar pula minat dan perhatiannya terhadap hal tersebut.

c. Asas Pengakuan

Asas pengakuan maksudnya memberikan penghargaan dan pengakuan yang tepat serta wajar kepada bawahan atas prestasi kerja yang dicapainya. Bawahan akan bekerja keras dan semakin rajin, jika merasa terus - menerus mendapat pengakuan dan kepuasan dari usaha usahanya.

Dalam memberikan pengakuan/ pujian kepada bawahan hendaknya dijelaskan bahwa dia patut menerima penghargaan itu, karena prestasi kerja atau jasa - jasa yang diberikan.Pengakuan dan pujian harus diberikan dengan ikhlas dihadapan umum supaya nilai pengakuan/pujian itu semakin besar.

d. Asas Wewenang yang Didelegasikan Yang dimaksud asas wewenang yang didelegasikan adalah mendelegasikan sebagian wewenang serta kebebasan karyawan untuk mengambil keputusan dan berkreatvitas dan melaksanakan tugas - tugas atasan atau manajer.Dalam pendelagasian ini, maajer harus meyakinkan bawahan bahwa karyawan mampu dan dipercaya dapat menyelesaikan tugas - tugas itu dengan baik. Asas ini akan memotivasi moral/gairah bekerja bawahan sehingga semakin tinggi dan antusias.

e. Asas Perhatian Timbal Balik

Asas perhatian timbal balik adalah memotivasi bawahan dengan 
mengemukakan keinginanan atau harapan perusahaan di samping berusaha memenuhi kebutuhan kebutuhan yang diharapkan bawahan dari perusahaan. Misalnya, mamanjer meminta supaya karyawan meningkatkan prestasi kerjanya sehingga perusahaan memperoleh laba yang lebih banyak. Apabila laba semakin banyak, balas jasa mereka akan dinaikkan. Jadi ada perhatian timbal balik untuk memenuhi keinginan semua pihak. Dengan asas motivasi ini diharapkan prestasi kerja karyawan akan meningkat.

\section{Metode Motivasi}

Ada dua metode motivasi yaitu motivasi langsung dan motivasi tidak langsung.

a. Motivasi Langsung ( Direct Motivation )

Motivasi langsung adalah motivasi ( materiil dan non materiil ) yag diberikan secara langsung kepada setiap individu karyawan untuk memenuhi kebutuhan serta kepuasannya. Jadi sifatnya khusus, seperti pujian, penghargaan, tunjangan hari raya, bonus, dan bintang jasa.

b. Motivasi Tak Langsung

Motivasi tak langsung adalah motivasi yang diberikan hanya merupakan fasilitas - fasilitas yang mendukung serta menunjang gairah kerja/kelancaran tugas sehingga para karyawan betah dan bersemangat melakukan pekerjaannya.Misalnya kursi yang empuk, mesin - mesin yang baik, ruangan kerja yang terag dan nyaman, suasana pekerjaanyang serasi, serta penempatan yang tepat.Motivasi tidak langsung besar pengaruhnya untuk merangsang semangat bekerja karyawan sehingga produktif.

\section{Alat - alat Motivasi}

Alat - alat motivasi ( daya perangsang ) yang diberikan kepada bawahan dapat berupa material incentive dan material mon incentive. Material incentive adalah motivasi yang bersifat materiil sebagai imbalan prestasi yang diberikan oleh karyawan. Yang termasuk material incentive adalah yang berbentuk uang dan barang.

Nonmaterial incentive adalah motivasi ( daya perangsang ) yang tidak berbentuk materi. Yang termasuk nonmaterial adalah penempatan yang tepat, pekerjaan yang terjamin, piagam penghargaan, bintang jasa, perlakuan yang wajar, dan sejenisnya.

\section{Jenis - jenis Motivasi}

Ada dua jenis motivasi, yaitu motivasi positif dan motivasi negative.

a. Motivasi positif

Motivasi positif maksudnya manajer memberikan motivasi (merangsang) bawahan dengan memberikan hadiah kepada mereka yang berprestasi di atas prestasi standar. Dengan motivasi yang positif, semangat kerja bawahan akan meningkat karena umumnya manusia senang menerima yang baik - baik saja.

b. Motivasi negatif

Motvasi negatif maksudnya manajer memberikan motivasi bawahan dengan standar mereka akan mendapat hukuman. Dengan motivasi negatif ini semangat bekerja bawahan dalam jangka waktu pendek akan meningkat karena mereka takut dihukum, tetapi untuk jangka waktu panjang dapat berakibat kurang baik. 
Dalam praktek, kedua jenis motivasi di atas sering digunakan oleh suatu perusahaan.Penggunaannya harus tepat dan seimbang supaya dapat meningkatkan semangat kerja karyawan.Yang menjadi masalah ialah kapan motivasi positif dan motivasi negatif dapat efektif merangsang gairah kerja karyawan.Motivasi efektif untuk jangka waktu panjang sedangkan motivasi negatif efektif untuk jangka pendek.Akan tetapi, manajer harus konsisten dan adil dalam menerapkannya.

\section{Proses Motivasi}

a. Tujuan

Dalam proses motivasi perlu ditetapkan terlebih dahulu tujuan organisasi baru kemudian para karyawan dimotivasi ke arah tujuan itu.

b. Mengetahui Kepentingan

Hal yang penting dalam proses motivasi adalah mengetahui keinginan karyawan dan tidak hanya mleihat dari sudut kepentingan pimpinan atau perusahaan

c. Komunikasi Efektif

Dalam proses motivasi harus dilakukan komunikasi yang baik dengan bawahan. Bawahan harus mengetahui apa yang akan diperolehnya dan syarat apa saja yang harus dipenuhinya supaya insentif tersebut diperolehnya.

d. Integrasi Tujuan

Proses motivasi perlu untuk menyatukan tujuan organisasi dan tujuan kepentingan karyawan. Tujuan organisasi adalah needscomplex yaitu untuk memperoleh laba serta perluasan perusahaan sedangkan tujuan individu karyawan ialah pemenuhan kebutuhan dan kepuasan. Jadi, tujuan organisasi dan tujuan karyawan harus disatukan dan untuk itu penting adanya penyesuaian motivasi.

e. Fasilitas

Manajer penting untuk memberikan bantuan fasilitas kepada organisasi dan individu karyawan yang akan mendukung kelancaran pelaksanaan pekerjaan, seperti memberikan bantuan kendaraan kepada salesman.

f. Team work

Manajer harus membentuk team work yang terkoordinasi baik yang bisa mencapai tujuan perusahaan. Team work.Penting karena dalam suatu perusahaan biasanya terdapat banyak bagian.

\section{Kerangka Pemikiran}

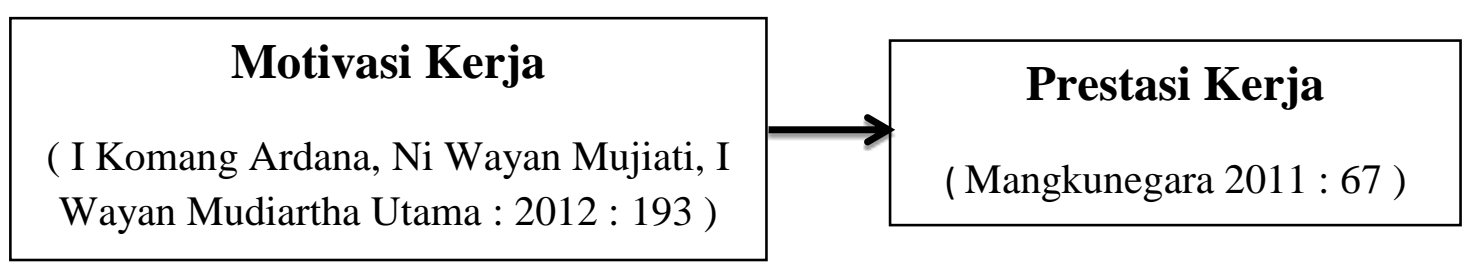

Gambar 1. Kerangka Pemikiran 


\section{Hipotesis}

Untuk menguji hipotesis yang telah diajukan yaitu : terdapat pengaruh antara Motivasi Kerja dengan Prestasi Kerja Karyawan, digunakan hipotesis nol dan hipotesis alternative.

Ho : $\quad \mathrm{b}=0$, tidak terdapat pengaruh motivasi kerja terhadap prestasi kerja karyawan dalam perusahaan PT Alva Karya Perkasa Bandung.

Ha $\quad$ : $\quad b \neq 0$, terdapat pengaruh motivasi kerja terhadap prestasi kerja karyawan dalam perusahaan PT Alva Karya Perkasa Bandung

\section{METODE PENELITIAN}

Metode penelitian yang digunakan adalah metode Deskriptif. Deskriptif adalah metode yang berfungsi untuk mendiskripsikan atau memberi gambaran terhadap obyek yang diteliti melalui data sample atau populasi sebagaimana adanya, tanpa melakukan analisis dan membuat kesimpulan yang berlaku untuk umum.

Pada metode deskriptif ini, akan dikemukan cara - cara penyajian data, dengan tabel biasa maupun distribusi frekuensi; grafik garis maupun batang; diagram lingkaran; pictogram; penjelasan kelompok melalui rentang dan simpangan baku. ( Sugiyono: 2015: 29 ).

\section{Populasi dan Sample}

Populasi adalah kumpulan dari keseluruhan pengukuran, objek, atau individu yang sedang dikaji. Pengertian populasi dalam statistik tidak terbatas pada sekelompok/kumpulan orang-orang, namun mengacu pada seluruh ukuran, hitungan, atau kualitas yang menjadi fokus perhatian suatu kajian. Suatu pengamatan/survey terhadap seluruh anggota populasi disebut sensus. Populasi sering juga disebut universe atau sekelompok individu atau objek yang memiliki karakteristik yang sama, misalnya status sosial sama, atau obyek lain yang mempunyai karakteristik sama seperti golongan darah. Dalam penelitian ini yang menjadi populasi adalah seluruh karyawan PT Alva Karya Perkasa sejumlah 249 orang.

Sedangkan sampel adalah sebagian, atau subset ( himpunan bagian ), dari suatu populasi. Populasi dapat berisi data yang besar sekali jumlahnya, yang mengakibatkan tidak mungkin atau sulit untuk dilakukan pengkajian terhadap seluruh data tersebut, sehingga pengkajian dilakukan terhadap sampelnya saja. Jadi, sampel merupakan bagian dari populasi, data yang diperoleh tidaklah lengkap. Namun jika pengambilan sampel dilakukan dengan mengikuti kaidahkaidah ilmiah, maka biasanya sangat mungkin diperoleh hasil-hasil dari sampel cukup akurat untuk menggambarkan populasi yang diperlukan dalam kajian yang dilakukan.

Oleh karena polpulasi sudah diketahui jumlah seluruhnya yaitu 249 orang karyawan, maka jumlah sample yang akan diteliti berdasarkan rumus Slovin (Ridwan, 2004 : 65 ) dalam skripsi Wahyudi, 2012 :

$$
n=\frac{N}{1+N(d)^{2}}
$$

Dimana $\mathrm{n}=$ sample $; \mathrm{N}=$ populasi $; \mathrm{d}=$ nilai presisi $10 \%$

$\mathrm{n}=249 / 249(0,1)^{2}+1=71,3$ dibulatkan 71

sample 


\section{Konsep Variabel}

Berdasarkan usulan judul yang diambil oleh penulis yaitu : " Pengaruh Motivasi Kerja Terhadap Prestasi Kerja Karyawan ". Maka terdapat dua variable dalam penelitian ini yaitu :

1. Variable $\mathrm{X}$ sebagai variable bebas yaitu variable yang mempengaruhi variable lainnya, dalam hal ini adalah Motivasi Kerja.

2. Variable Y sebagai variable terikat yaitu variable yang dipengaruhi oleh variable bebas, dalam hal ini adalah Prestasi Kerja Karyawan.

\section{Metode Analisis Data \\ Uji validasi}

Menurut Umar (2007:52) uji validitas adalah metode pengujian yang digunakan untuk mengetahui apakah ada pertanyaan-pertanyaan koesioneryang harus dibuang atau diganti karena dianggap tidak relevan . Pengujiannya dilakukan secara statistic. Teknik untuk mengukur validasi koesioner adalah dengan menghitung korelasi antara data pada masing-masing pernyataan dengan skor total. Item instrument dianggap valid jika lebih besar dari 0,30 atau bias juga dengan membandinngkannya dengan $r$ table.

Hal ini diperkuat oleh Sugiyono (2004) bahwa: "ketentuan validitas instrument yang kuat, apabila nilai korelasi (r) dihitung lebih besar dari $r$ kritis yaitu 0,3 . Selain ini Sugiyono menambahkan bahwa bila korelasi tiap faktor adalah positif dan besarnya $0,3 \mathrm{ke}$ atas maka faktor tersebut merupakan construct yang kuat."

Korelasi dapat menghasilkan angka positif (+) atau negatif (-). Jika korelasi menghasilkan angka positif (+), hubungan kedua variabel bersifat searah. Jika korelasi menghasilkan angka yang negatif (-), hubungan kedua variabel bersifat tidak searah. Angka korelasi berkisar antara 0 sampai dengan 1, besar kecilnya angka korelasi menentukan kuat atau lemahnya hubungan kedua variabel.

\section{Uji Reliabilitas}

Pengujian realiabilitas dilakukan dengan internal consistency, dengan cara mencobakan instrumen sekali saja kemudian yang diperoleh dianalisis dengan teknik tertentu. Uji reliabilitas dilakukan dengan menggunakan metode Alpha Cronbach's yang diukur berdasarkan skala Alpha Cronbach's.

\section{Uji Statistik \\ Analisis Kolerasi}

Menurut Sujiono ( 2007 : 37 ), korelasi itu berarti hubungan, begitu pula analisis korelasi yaitu suatu analisis yang digunakan untuk melihat hubungan antar 2 variabel. Uji korelasi tidak membedakan jenis variable ( tidak ada variable dependen maupun independen ). Jika sampel data lebih dari 30 ( sampel besar ) dan kondisi normal, sebaiknya menggunakan korelasi Pearson karena memenuhi asumsi parametrik. Jika jumlah sampel kurang dari 30 ( sampel kecil ) dan kondisi data tidak normal maka sebaiknya menggunakan korelasi Spearman atau Kendall karena memenuhi asumsi non parametrik. Dengan ini peneliti memilih untuk menggunakan korelasi Spearman Rank ( $\rho$ ) karena semua data dalam penelitian ini memenuhi asumsi non parametric dan berskala ordinal.

\section{Analisis Regresi \\ Menurut Sugiyono ( $2015: 260$ ) \\ analisis regresi digunakan untuk memprediksikan seberapa jauh perubahan nilai variable dependen, bila nilai variable}


independen di manipulasi / dirubah rubah atau dinaik - turunkan. Manfaat dari hasil analisis regresi adalah adalah untuk membuat keputusan apakah naik dan menurunnya variable dependen dapat dilakukan melalui peningkatan variable independen atau tidak.

Regresi sederhana didasarkan pada hubungan fungsional ataupun kausal satu variable independen dengan satu variable dependen. Persamaan umum regresi linier sederhana adalah :

$$
\mathrm{Y}=\mathrm{a}-\mathrm{bX}
$$

Dimana :

$\mathrm{Y}=\quad$ Subyek dalam variable dependen yang diprediksikan

$\mathrm{a}=$ Harga $\mathrm{Y}$ ketika harga $\mathrm{X}=0$ ( harga konstan ).

$\mathrm{b}=\quad$ Angka arah atau koefisien regresi, yang menunjukan angka peningkatan ataupun penurunan variable dependen yang didasarkan pada perubahan variable independen. Bila $(+)$ arah garis naik, dan bila ( - ) maka arah garis turun.

$X=$ Subyek pada variable independen yang mempunyai nilai tertentu.

\section{Pengujian Hipotesis}

Untuk menguji hipotesis nol, dipakai statistik $\mathrm{F}=\frac{S^{2} r e g}{S^{2} r e g}$ (F hitung) Untuk menguji hipotesis nol, kriterianya adalah tolak hipotesis nol apabila koefisien $\mathrm{F}$ hitung lebih besar dari harga $\mathrm{F}$ tabel berdasarkan taraf kesalahan yang dipilih dan $\mathrm{dk}$ yang bersesuaian. Kesimpulan koefisien itu berarti $(b \neq 0)$.

\section{ANALISIS \\ DATA PEMBAHASAN \\ 4.1.1 Data Responden \\ Di dalam penelitian ini dikumpulkan data primer untuk mengetahui Pengaruh motivasi kerja terhadap prestasi kerja karyawan dalam}

perusahaan PT Alva Karya Perkasa Bandung melalui penyebaran kuesioner kepada 50 responden yang menjadi sampel penelitian. Pada analisis deskriptif ini, data responden dijelaskan melalui tabel tunggal. Data responden dalam penelitian ini sangat dibutuhkan untuk mengetahui latar belakang responden yang dapat dijadikan masukan untuk menjelaskan hasil yang diperoleh dari penelitian. Analisis deskriptif data responden ini terdiri atas 4 tabel tunggal berisi data mengenai lama bekerja, jenis kelamin, pendidikan terakhir, dan status dengan data sebagai berikut:

- responden berdasarkan lama bekerja. Seluruh responden sebanyak 25 orang atau $50 \%$ adalah responden yang lama bekerjanya antara 1-3 tahun sedangkan yang paling sedikit adalah responden yang lama bekerjanya antara $0-3$ bulan yaitu sebanyak 4 orang atau $8 \%$.

- responden berdasarkan jenis kelamin. Mayoritas responden sebanyak 35 orang atau $70 \%$ adalah perempuan dan sisanya adalah laki-laki yaitu sebanyak 15 orang atau $30 \%$

- responden berdasarkan pendidikan terakhir. Mayoritas responden sebanyak 43 orang atau $86 \%$ adalah responden yang SMA dan paling sedikit adalah responden yang pendidikan terakhirnya S1 yaitu sebanyak 2 orang atau $4 \%$.

- responden berdasarkan status. Mayoritas responden sebanyak 28 orang atau $56 \%$ adalah adalah responden yang statusnya menikah dan paling sedikit adalah responden yang statusnya belum menikah yaitu sebanyak 22 orang atau $44 \%$.

\section{Uji Validitas dan Reliabilitas}


Sebelum angket digunakan untuk pengumpulan data, maka terlebih dahulu diuji melalui validitas dan reabilitas menggunakan metode korelasi Pearson Product Moment dan Alpha Cronbach. Berikut disajikan hasil uji validitas dan reliabilitas untuk seluruh pernyataan. Hasil penelitian menggambarkan bahwa seluruh item pertanyaan menunjukkan hasil yang valid. Sedangkan hasil uji reliabilitas pada variabel tersebut menunjukkan hasil yang reliabel. Dengan demikian data tersebut dapat digunakan untuk analisis selanjutnya.

\section{Koefisien Korelasi Product Moment}

Analisis ini digunakan untuk mengetahui derajat atau kekuatan hubungan antara variabel X (Motivasi Kerja) dengan variabel Y (Prestasi Kerja) secara bersamaan. Dengan menggunakan SPSS versi 19 didapat output sebagai berikut:

Model Summary

\begin{tabular}{|l|r|r|r|r|}
\hline Model & $\mathrm{R}$ & $\mathrm{R}$ Square & $\begin{array}{c}\text { Adjusted } \\
\text { R Square }\end{array}$ & $\begin{array}{r}\text { Std. Error of } \\
\text { the Estimate }\end{array}$ \\
\hline 1 &, $702^{\mathrm{a}}$ &, 493 &, 483 & 3,76219 \\
\hline
\end{tabular}

a. Predictors: (Constant), Motiv asi Kerja

Dari analisis diatas dapat variabel $X$ (Motivasi Kerja) terhadap diketahui bahwa nilai koefisien korelasi variabel Y (Prestasi Kerja). Tujuannya adalah sebesar 0,702. Nilai tersebut untuk meramalkan atau memperkirakan termasuk kedalam korelasi yang kuat dan nilai variabel dependen dalam merupakan korelasi positif, yaitu berada hubungannya dengan nilai variabel lain. diantara 0,600 - 0,799.

Dari hasil perhitungan dengan menggunakan SPSS versi 19, maka

\section{Analisis Persamaan Regresi Linier} Sederhana

Analisis ini dimaksudkan untuk mengetahui adanya pengaruh antara diperoleh output dan persamaan hubungan regresi sederhana sebagai berikut :

\section{Coefficients ${ }^{\mathrm{a}}$}

\begin{tabular}{|c|c|c|c|c|c|c|}
\hline \multirow{2}{*}{\multicolumn{2}{|c|}{ Model }} & \multicolumn{2}{|c|}{$\begin{array}{l}\text { Unstandardized } \\
\text { Coeff icients }\end{array}$} & \multirow{2}{*}{$\begin{array}{l}\text { Standardized } \\
\text { Coeff icients } \\
\text { Beta }\end{array}$} & \multirow[b]{2}{*}{$t$} & \multirow[b]{2}{*}{ Sig. } \\
\hline & & B & Std. Error & & & \\
\hline \multirow[t]{2}{*}{1} & (Constant) & 11,495 & 2,052 & & 5,601 &, 000 \\
\hline & Motivasi Kerja & ,722 & , 106 & ,702 & 6,835 & ,000 \\
\hline
\end{tabular}

a. Dependent Variable: Prestasi Kerja

$$
\mathrm{Y}=\mathrm{a}+\mathrm{bX}
$$


Dimana $: \mathrm{Y}=$ Motivasi Kerja; $\mathrm{a}=$ Nilai intersep (konstanta); $\mathrm{X}=$ Prestasi Kerja; $\mathrm{b}=$ Koefisien regresi.

Dari hasil pengolahan SPSS di atas didapat nilai $\mathrm{a}=11,495$ dan nilai $\mathrm{b}=$ 0,722 . Dengan demikian diperoleh persamaan regresi linier berganda sebagai berikut:

$$
\mathrm{Y}=11,495+0,722 \mathrm{X}
$$

Persamaan di atas dapat diartikan sebagai berikut:

$\mathrm{a}=11,495$ : artinya jika motivasi kerja (X) bernilai nol (0), maka prestasi kerja (Y) akan bernilai 11,495.

$\mathrm{b}=0,722 \quad$ : artinya jika motivasi kerja (X) meningkat sebesar satu satuan, maka prestasi kerja (Y) akan meningkat sebesar 0,722 satuan.

\section{Analisis Koefisien Determinasi}

Setelah didapat nilai koefisien perhitungan persentase pengaruh variabel $\mathrm{X}$ terhadap variabel $\mathrm{Y}$ digunakan rumus Koefisien Determinasi (KD) sebagai berikut : $\mathrm{KD}=\left(\mathrm{r}_{\mathrm{xy}}\right)^{2} \mathrm{x} 100 \%$

Dimana : KD = koefisien determinasi;

$\left(\mathrm{r}_{\mathrm{xy}}\right)^{2}=$ koefisien korelasi product moment

Model Summary

\begin{tabular}{|l|r|r|r|r|}
\hline Model & R & R Square & $\begin{array}{c}\text { Adjusted } \\
\text { R Square }\end{array}$ & $\begin{array}{r}\text { Std. Error of } \\
\text { the Estimate }\end{array}$ \\
\hline 1 &, $702^{\mathrm{a}}$ &, 493 &, 483 & 3,76219 \\
\hline
\end{tabular}

a. Predictors: (Constant), Motivasi Kerja

$$
\mathrm{KD}=\mathrm{r}_{\mathrm{yx}}{ }^{2} \mathrm{x} 100 \%=(0,702)^{2} \times 100 \%=49,325 \%
$$

Dari analisis diatas dapat dilihat bahwa variabel $X$ (Motivasi Kerja) memiliki pengaruh terhadap variabel $\mathrm{Y}$ (Prestasi Kerja) sebesar 49,325\%, sedangkan sisanya sebesar $50,675 \%$ dipengaruhi oleh faktor lain yang tidak diamati.

\section{Pengujian Hipotesis (Uji-t)}

Setelah dilakukan analisis koefisien determinasi maka kemudian dilakukan pengujian hipotesis untuk menguji apakah terdapat pengaruh yang signifikan atau tidak antara kedua variabel dengan menggunakan uji-t sebagai berikut:

$$
\begin{array}{ll}
\mathrm{H}_{0}: \mathrm{b}=0, & \text { artinya Motivasi } \\
& \text { Kerja tidak } \\
& \text { memberikan } \\
& \text { pengaruh yang } \\
& \text { signifikan terhadap } \\
& \text { Prestasi Kerja. } \\
& \text { artinya Motivasi } \\
& \text { Kerja memberikan } \\
\mathrm{H}_{1}: \quad \mathrm{b} \neq 0, \quad \text { pengaruh yang } & \text { signifikan terhadap } \\
& \text { Prestasi Kerja }
\end{array}
$$

Dengan menggunakan program SPSS versi 19 didapat output sebagai berikut: 
Coefficients $^{\mathrm{a}}$

\begin{tabular}{|c|c|c|c|c|c|c|}
\hline \multirow[b]{2}{*}{ Model } & & \multicolumn{2}{|c|}{$\begin{array}{l}\text { Unstandardized } \\
\text { Coeff icients }\end{array}$} & \multirow{2}{*}{$\begin{array}{l}\text { Standardized } \\
\text { Coeff icients } \\
\text { Beta }\end{array}$} & \multirow[b]{2}{*}{$t$} & \multirow[b]{2}{*}{ Sig. } \\
\hline & & B & Std. Error & & & \\
\hline & (Constant) & 11,495 & 2,052 & & 5,601 &, 000 \\
\hline & Motivasi Kerja &, 722 & 106 & .702 & 6,835 & .000 \\
\hline
\end{tabular}

a. Dependent Variable: Prestasi Kerja

Dari hasil pengolahan SPSS di atas didapat nilai thitung sebesar 6,835. Dengan alpha $(\alpha)=5 \%$ dan derajat kebebasan $(\mathrm{dk})$ $=\mathrm{n}-2=48$, maka berdasarkan tabel distribusi-t dua pihak didapat nilai $t_{\text {tabel }}$ sebesar 2,011. Nilai $t_{\text {hitung }}$ dan $t_{\text {tabel }}$ tersebut kemudian diuji menggunakan kriteria pengujian sebagai berikut:

Jika $t_{\text {hitung }} \geq \mathrm{t}_{\text {tabel }}$ atau $-\mathrm{t}_{\text {hitung }} \leq-\mathrm{t}_{\text {tabel }}$, maka $\mathrm{H}_{0}$ ditolak.

Jika $t_{\text {hitung }}<t_{\text {tabel }}$ atau $-t_{\text {hitung }}<-t_{\text {tabel }}$, maka $\mathrm{H}_{0}$ diterima.

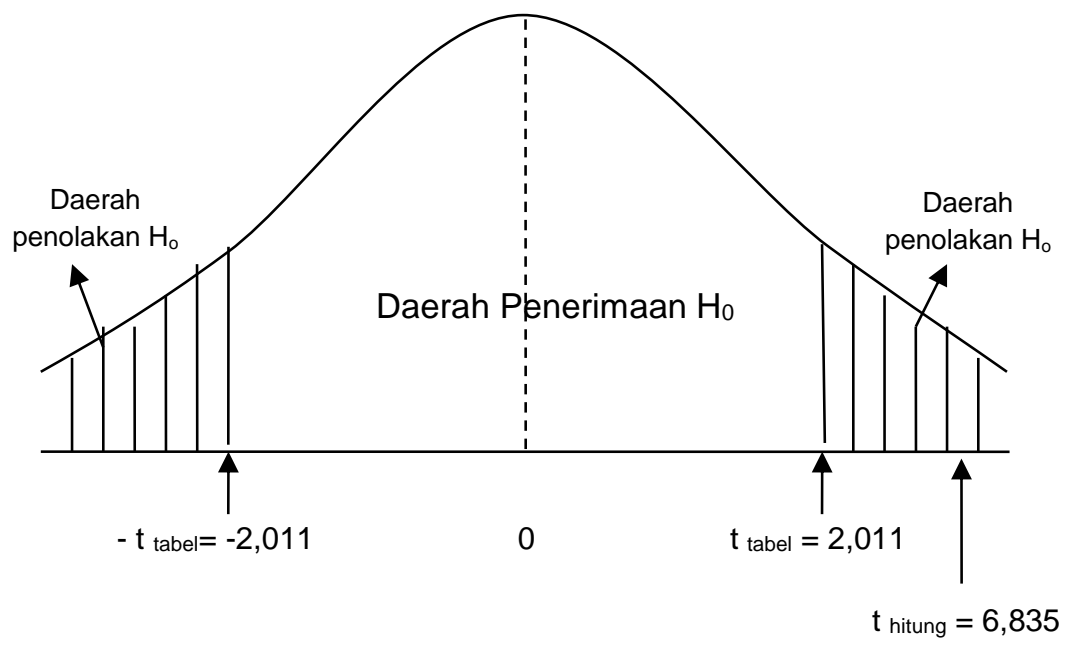

Gambar 4.12 Kurva Uji-t Dua Pihak

Dikarenakan nilai thitung lebih besar daripada $t_{\text {tabel }}(6,835>2,011)$ maka $\mathrm{H}_{0}$ ditolak dan $\mathrm{H}_{1}$ diterima. Hal ini menunjukkan adanya pengaruh yang signifikan an tara Motivasi Kerja terhadap Prestasi Kerja, dengan kata lain kita dapat mempercayai 95\% bahwa Motivasi Kerja berpengaruh terhadap Prestasi Kerja.

\section{SIMPULAN DAN SARAN}

Berdasarkan hasil analisis deskriptif data penelitian untuk variabel Motivasi Kerja, maka dapat disimpulkan bahwa tanggapan responden tentang Motivasi Kerja termasuk dalam kategori "Rendah".

Berdasarkan hasil analisis deskriptif data penelitian untuk variabel Prestasi Kerja, maka dapat disimpulkan bahwa 
tanggapan responden tentang Prestasi Kerja termasuk dalam kategori "Rendah". Berdasarkan keseluruhan pemaparan analisis perhitungan statistik pada uji korelasi, koefisien determinasi, dan uji hipotesis, dapat diambil kesimpulan bahwa, secara statistik, pengaruh Motivasi Kerja telah terbukti mempunyai korelasi yang kuat dan signifikan terhadap Prestasi Kerja, dengan pengaruh sebesar 49,325\%. Sedangkan sisa pengaruh sebesar $50,675 \%$ dipengaruhi oleh faktor lain yang tidak diamati.

Agar motivasi berupa material dapat ditingkatkan paling tidak ada tambahan komponen pada gaji yang diberikan kepada karyawan guna untuk meningkatkan prestasi kerja hendaknya dalam hal ini menuntut pemimpin mempertimbangkan dan memperhitungkan komponen gaji kepada karyawan apalagi jika dibandingkan dengan gaji diperusahaan kompetitor.

Hasil penelitian menunjukan bahwa tingkat prestasi kerja karyawan PT Alva Karya Perkasa belum mencapai tingkat yang optimal. Perlu diperhatikan situasi dan kondisi karyawan, jika memungkinkan terapkan ketegasan agar pimpinan dan karyawan memiliki tujuan yang sama yaitu mencapai target semaksimal mungkin sehingga prestasi perusahaan pun akan meningkat.

Untuk meningkatkan prestasi kerja karyawan yang diharapkan, PT. Alva Karya Perkasa Bandung hendaknya menjadi karyawan yang memiliki kualitas serta professional yang tinggi dalam bekerja dengan memberikan pelatihan pelatihan yang menunjang pekerjaan mereka.

Dari hasil penelitian keseluruhan yang berpengaruh terhadap prestasi yang lebih dari 50\% adalah di luar dari motivasi kerja, hendaknya perusahaan memikirkan hal lain apa saja yang dapat meningkatkan prestasi kerja karyawan tersebut selain daripada motivasi kerja. Misalnya, mulai melihat lingkungan sekitar pekerjaan atau tinggi rendahnya turn over pada karyawan.

\section{DAFTAR PUSTAKA}

A.A.Anwar Prabu Mangkunegara. 2011. Manajemen Sumber Daya Manusia Perusahaan. PT.Remaja Rosda Karya, Bandung

Arikunto, Suharsimi. 2002.Prosedur Penelitian-Suatu Pendekatan Praktek,Cetakan Kedua Belas (Edisi Revisi V). Jakarta: PT. Rineka Cipta.

Ardana, I. K., Mujiati, N. W., \& Utama, I. W. 2012. Manajemen Sumber Daya Manusia Edisi Pertama. Yogyakarta: Graha Ilmu.

Bambang Wahyudi. 2002. Manajemen Sumber Daya Manusia. Bandung: Sulita

Davis, Keith and John W. Newstrom. (1985).Human Behaviour at Work : Organizational Behaviour. Mc. Graw-Hill Inc., New York

Hasibuan, Malayu. 2012. "Manajemen Sumber Daya manusia". Jakarta: PT Bumi Aksara.

Hersey, P dan Kenneth. H. Blanchard. 1982. Manajemen: Perilaku Organisasi Jakarta: PT. Erlangga.

Kartasasmita, Gianjar Dan Siagian, 1994, Pembangunan Infrastruktur Seminar Pembangunan Konsep Dan Implikasi. Fakultas Ilmu Sosial Dan Politik, Yogjakarta: Universitas Gadjah Mada

Mc.Clelland, David C. 1987. Human Motivation. Cambridge University Press 
Porter \& Lawler, 1968; Vroom, V., Work and Motivation (New York: john Wiley, 1964. dalam buku Sedarmayanti (2007) Manajemen Sumber Daya Manusia (Reformasi Birokrasi dan Manajene PNS), Ed 1, Bandung : Refika Aditama.

Riduwan, Rusyana A, dan Enas. 2011. Cara Mudah Belajar SPSS Versi 17.0 dan Aplikasi Statistik Penelitian. Bandung: Alfabet
Soedarmayanti. 2009. Reformasi Administrasi Publik, Reformasi Birokrasi, dan Kepemimpinan Masa Depan. Bandung. Refika Aditama.

Sugiono (2012), Metodologi Penelitian Bisnis, Cetakan Ke XII, CV. Alfabeta,Bandung.

http://www.pengertianahli.com/2013/11/ pengertian-populasi-dansampel.html\# 